\title{
Higher production of $\gamma$-aminobutyric acid in Toxicodendron vernicifluum extract by co-fermentation using yeast and lactic acid bacteria
}

\author{
Hye-Mi Kang ${ }^{1}$, Jong-Soon Lim ${ }^{2}$, Sam-Pin Lee ${ }^{1,2 *}$ \\ ${ }^{1}$ Department of Food Science and Technology, Keimyung University, Daegu 42601, Korea \\ ${ }^{2}$ The Center for Traditional Microorganism Resource, Keimyung University, Daegu 42601, Korea
}

\section{옻나무 추출물의 효모-젖산균 혼합발효를 통한 고농도 $\gamma$-aminobutyric acid 생산}

\author{
강혜미 ${ }^{1} \cdot$ 임종순 $^{2} \cdot$ 이삼빈 ${ }^{1,2 *}$ \\ ${ }^{1}$ 계명대학교 식품가공학과, ${ }^{2}$ 계명대학교 전통미생물자원개발 및 산업화연구센터
}

\begin{abstract}
Toxicodendron vernicifluum extract (TVE) was co-fermented by Saccharomyces cerevisiae and Lactobacillus plantarum EJ2014 to produce higher content of gamma-aminobutyric acid (GABA). The TVE was cultured at $30^{\circ} \mathrm{C}$ for 2 days under static conditions with sucrose $5 \%$, yeast extract $1 \%$, and Saccharomyces cerevisiae starter $1 \%$. The second lactic acid fermentation after the primary first yeast fermentation was performed at $30{ }^{\circ} \mathrm{C}$ for 7 days after adding monosodium L-glutamate (MSG) $2.5 \%$, lactose $2.5 \%$ and lactic acid bacteria (LAB) starter $\mathbf{1 \%}$. The first fermented TVE showed $\mathrm{pH} 4.6,0.1 \%$ acidity and viable cell counts of $S$. cerevisiae $7.63 \mathrm{log} \mathrm{CFU} / \mathrm{mL}$. After the second fermentation, co-fermented TVE showed $\mathrm{pH} 4.64,0.68 \%$ acidity, and viable cell count of $L$. plantarum EJ2014 $7.68 \log$ CFU/mL. During the co-fermentation with $S$. cerevisiae and L. plantarum EJ2014, the MSG was completely converted, yielding $2.5 \%$ GABA. Conclusively, co-fermentation of TVE was successfully performed with $S$. cerevisiae and $L$. plantarum EJ2014, resulting in a higher production of GABA and probiotics. The final fermented TVE could be utilized as a multi-functional ingredient in food and bio-industries.
\end{abstract}

Key words: Toxicodendron vernicifluum, monosodium L-glutamate, Saccharomyces cerevisiae, Lactobacillus plantarum, $\gamma$-aminobutyric acid

\section{서 론}

현대인들의 삶의 질이 향상되어가면서 식품의 역할이 생 명유지의 기능 외에도 건강 증진 및 기호도가 중요시되고 있 다. 최근 천연소재를 발효하여 개발된 발효식품은 세계적인 건강식품으로 인정받고 있다. 이러한 발효식품은 사용되는 미생물의 종류와 발효원료에 따라 매우 다양하며, 미생물의 작용 때문에 단백질 등의 원료 성분이 분해되기도 하고, 새로
운 성분이 합성되기도 하여 영양성분과 기능성, 저장성 및 기 호도가 향상된다.

옻은 옻나무과에 속하는 낙엽활엽교목으로 학명은 Rhus verniciflua Stokes 또는 Toxicodendron vernicifluum 이며, 전 세계적으로도 약 600여 종이 존재하고 있는 것으로 알려져 있고, 우리나라에는 참 옻나무를 포함한 6종의 옻나무가 분 포하고 있다(Kim 등, 2002; Lim 등, 2018).

옻나무는 항암, 항산화, 유전독성 및 세포 고사의 조절과

${ }^{*}$ Corresponding author. E-mail : splee@kmu.ac.kr, Phone :+82-53-580-5554, Fax : +82-53-580-5729

Received 16 November 2020; Revised 21 December 2020; Accepted 22 December 2020.

Copyright (c) The Korean Society of Food Preservation.

This is an Open Access article distributed under the terms of the Creative Commons Attribution Non-Commercial License (http://creativecommons.org/licenses/by-nc/4.0) which permits unrestricted non-commercial use, distribution, and reproduction in any medium, provided the original work is properly cited. 
정, 면역증강 등의 효과가 밝혀지면서 옻나무의 식품사용 및 재배면적이 증가하고 있으며, 다량의 항산화 물질이 함유되 어 있다(Jin 등, 2017). 최근에는 이를 이용한 식품의 원료로 시판되고 있으며, 옻나무 추출물의 생리활성에 관한 연구도 활발히 진행되고 있다(Choi 등, 2010).

전통 발효 미생물 중 효모와 젖산균은 대표적인 발효 미생 물이며, 발효에 이용되는 균주마다 발효물의 성분이나 기능 성이 크게 달라지기 때문에 발효의 최적화를 위해서는 균주 의 선택이 중요하다. 일반적인 발효의 경우 대부분 단일 균주 를 이용하는 발효법을 이용하지만, 우리가 주로 먹는 김치, 청국장과 같은 발효식품에서 미생물을 분리해보면 다양한 종 류의 미생물이 함께 발효에 관여한다.

Saccharomyces cerevisiae는 인체에 안전한 GRAS 균주로 핵산, 효소, 단백질, 지질, 미네랄 등의 원료로 사용되어 왔고 (Lee 등, 2009), 다양한 생리 활성 물질 생산에 관한 연구를 통해 항치매 $\beta$-secretase 저해물질(Lee 등, 2007), 항고혈압성 안지오텐신 전환효소 저해물질(Kim 등, 2011), 항혈전 용해 활성물질(Jang 등, 2011) 등의 다양한 생리 기능성 물질을 생 성하여 건강식품의 공급원으로 사용되고 있다(Jeong 등, 2019).

젖산균은 대표적인 probiotics로 당류를 발효하여 젖산을 생성하는 통성혐기성 세균으로서 전통적인 발효식품의 제조 에 관여한다. 특히 젖산균에 의한 발효를 통한 단백질 및 대 사산물 생산, 지방분해 작용으로 발효식품의 저장성과 기능 성을 높이며, 식품의 풍미를 향상시킨다(Carr 등, 2002). 또 한, 젖산균은 혈중 콜레스테롤과 혈압 수치를 낮추며, 체내 대사 활성에 긍정적인 영향을 주어 암 생성 억제, 위장염 억 제 등과 같은 효과가 보고되었다(Kim 등, 2017). 특히 Lactobacillus brevis, Lactobacillus paracasei, Lactococcus lactis, Lactobacillus delbrueckii, Lactobacillus plantarum 등 과 같은 젖산균은 전구물질 monosodium L-glutamate(MSG) 로부터 기능성 물질인 $\mathrm{GABA}$ 를 생합성하는 특징을 가지고 있다고 보고되었다(Kim, 2013; Lim, 2013; Park, 2019).

L-Glutamic acid는 중추신경계의 신경전달물질로 신경세 포 활성을 유도하는 물질로 알려져 있고, glutamate decarboxylase(GAD, EC4.1.1.15)에 의해 $\gamma$-aminobutyric acid (GABA)로 전환된다(Park, 2001). GABA는 자연계에 널리 분 포되어있고, 4 개의 탄소로 구성되어있는 비단백성 아미노산 이다. 이는 포유동물의 뇌나 척수에 존재하는 억제성 신경전 달 물질이며, 전체 중주 신경 물질의 약 $30 \%$ 를 차지하고 있 다(Oh, 2005). GABA는 혈류를 개선하며, 뇌의 산소공급을 증가시키며 뇌의 대사촉진 및 뇌 기억을 증진하는 뇌의 영양 제로 알려져 있으며, 중풍, 치매 예방, 기억력 증진, 불면 등 에 효과가 있다고 보고되었다(Park, 2001). 또한, 식욕과 포 만감에 영향을 주어 체중을 감소시키는 효과가 있으며, 이 물
질의 극심한 농도 감소는 발작, 경련을 유발하기도 한다고 보고되었다(Kim 등, 1999; Oh, 2005; Park, 2001). 미생물에 의한 GABA 합성은 기질인 glutamate로부터 GABA 합성 효 소인 L-glutamic acid decarboxylase(GAD)와 보조인자인 pyridoxal-5-phosphate(PLP)에 의해 생합성되는 것으로 알려 져 있다(Kim 등, 1999).

따라서 본 연구의 목적은 항산화성 및 다양한 기능성을 함 유하는 것이 입증된 옻나무 추출물에 효모와 젖산균의 혼합 발효를 최적화하여 고농도 $\mathrm{GABA}$ 를 생산하는 것이며, 이를 통해 GABA, probiotics 등 생리활성물질이 강화된 옻 발효 식품소재 개발을 위한 기초 연구 자료를 제공하고자 한다.

\section{재료 및 방법}

\section{실험재료}

본 실험에 사용한 옻나무 추출물(Toxicodendron vernicifluum extract, TVE)은 옻가네 식품(Chungchungbukdo, Korea)에서 생산된 원료를 제공받아 $-18^{\circ} \mathrm{C}$ 에서 냉동 보관하여 사용하였 다. 탄소원으로 사용된 설탕(sucrose)과 lactose는 각각 대한 제당(KS H-2003, Incheon, Korea)과 (주덕산약품공업(Ansan, Korea)으로부터 구입하였다. Yeast extract(YE)는 (주조홍 (Ansan, Korea)으로부터 제품을 구입하여 사용하였다. 표준 물질 GABA는 Sigma-Aldrich 사(St. Louis, MO, USA)에서 구입하였으며, glutamic acid는 Thermo scientific 사(Rockford, IL, USA) 제품을 구입하여 사용하였다.

\section{스타터 배양액 제조}

Saccharomyces cerevisiae는 빵에서 분리된 효모로서 MRS agar plate에서 계대배양한 후, 멸균한 MRS broth에 순 수 배양된 S. cerevisiae 한 백금이 접종한 뒤 항온배양기 $30^{\circ} \mathrm{C}$ 에서 24 시간 동안 정치 배양하여 1 차 효모발효 스타터로 사 용하였다.

Lactobacillus plantarum EJ2014(KCCM 11545P)는 쌀겨 (Uljin, Korea)에서 분리된 GABA 생성능이 우수한 균주로 서, MRS agar plate에서 계대 배양한 후, 멸균한 MRS broth 에 순수 배양된 L. plantarum 한 백금이 접종한 뒤 $30^{\circ} \mathrm{C}$ 항온 배양기에서 24시간 동안 정치 배양하여 2차 젖산균 발효 스 타터로 사용하였다.

\section{1차 효모발효}

$121^{\circ} \mathrm{C}$ 에서 15 분간 멸균된 옻나무 추출물 $15 \mathrm{~mL}$ 에 sucrose $5 \%(\mathrm{w} / \mathrm{v})$ 와 yeast extract $1 \%(\mathrm{w} / \mathrm{v})$ 를 $250 \mathrm{~mL}$ baffle flask에 혼합한 뒤 최종 부피 $100 \mathrm{~mL}$ 가 되도록 멸균수를 첨가하였 다. 그 다음 S. cerevisiae 스타터 $1 \%(\mathrm{w} / \mathrm{v})$ 를 접종하여 항온배 양기에서 $30^{\circ} \mathrm{C}$ 로 2 일간 정치 배양한 후 발효물의 이화학적 
분석을 하였다.

\section{2차 젖산균 발효}

$\mathrm{GABA}$ 생산을 위한 2차 젖산균 발효는 1차 효모 발효물에 MSG $5 \%(\mathrm{w} / \mathrm{v})$ 와 lactose $2.5 \%(\mathrm{w} / \mathrm{v})$ 를 첨가한 후 부피를 200 $\mathrm{mL}$ 가 되도록 멸균수를 첨가하였다. 그다음 L. plantarum 스 타터 $1 \%(\mathrm{w} / \mathrm{v})$ 를 추가적으로 접종하여 항온배양기에서 $30^{\circ} \mathrm{C}$ 로 7일간 정치 배양한 옻 발효물의 이화학적 분석을 하였다.

\section{$\mathrm{pH}$ 및 적정산도 측정}

옻 발효물의 적정 산도는 시료 $1 \mathrm{~mL}$ 에 증류수 $9 \mathrm{~mL}$ 를 가 하여 희석 후 $\mathrm{pH}$ 8.3에 도달할 때까지 $0.1 \mathrm{~N} \mathrm{NaOH}$ 로 적정 하여 사용된 소비량을 lactic acid 함량 $(\%, \mathrm{w} / \mathrm{v})$ 으로 환산하여 측정하였으며, $\mathrm{pH}$ 는 $\mathrm{pH}$ meter(SevenCompact ${ }^{\mathrm{TM}} \mathrm{pH} / \mathrm{Ion}$ S220, Mettler-Toledo AG, Schwerzenbach, Switzerland)를 이용하여 측정하였다.

\section{생균수 측정}

생균 수는 발효물을 멸균 생리식염수로 $10^{6}$ 까지 단계별 희 석한 것을 MRS agar 배지에 $20 \mu \mathrm{L}$ 도말한 후 배양한다. $S$. cerevisiae와 L. plantarum EJ2014는 MRS agar plate에서 3 $0^{\circ} \mathrm{C}$ 항온배양기에서 각각 48 시간 배양한 후 생균수를 $\log$ colony forming unit(CFU)/mL로 나타내었다.

\section{수분 및 고형분 함량 측정}

수분 및 고형분 함량은 $105^{\circ} \mathrm{C}$ 에서 상압가열건조시켜 감소 하는 양을 수분함량으로 측정하였다.

\section{환원당 함량 측정}

환원당 함량은 dinitrosalicylic acid(DNS)법에 의해 측정 하였다(Im 등, 2019). 옻 추출 혼합 발효물을 원심분리기 (Eppendorf, Germany)를 이용하여 13,000 rpm, 15분 동안 원심분리를 하여 얻은 상등액을 희석한 시료 $1 \mathrm{~mL}$ 에 DNS 시약 $3 \mathrm{~mL}$ 를 가하고, $100^{\circ} \mathrm{C}$ 에서 5 분간 발색시킨다. 실온의 암소에서 40 분간 냉각 후 $550 \mathrm{~nm}$ 에서 흡광도를 측정하였다.

\section{무기질 함량 측정}

옻나무 추출물의 무기질 분석은 식품공전(MFDS(2014) Ministry of Food and Drug Safety, Food Code II, Cheongju, Korea, P)의 방법에 따라 수행하였으며, 무기질 중 $\mathrm{Na}, \mathrm{Ca}$, $\mathrm{K}, \mathrm{Mg}, \mathrm{P}, \mathrm{Fe}, \mathrm{Mn}$ 함량의 측정은 건식분해법에 따라 시험용 액을 조제하고 ICP-OES로 정량하였다. 시료를 균질화하여 일 정량(약 $10 \mathrm{~g})$ 을 회화 용기에 취한 후 탄화시키고, $550-600^{\circ} \mathrm{C}$ 의 온도에서 여러 시간 회백색이 될 때까지 회화하였다. 방냉
후 염산용액 $10 \mathrm{~mL}$ 를 가해 수욕상에서 완전 증발 건고시키 고, 건고물에 염산용액 8-10 mL를 가하여 수분 가열한 다음 $50 \mathrm{~mL}$ 정용플라스크에 여과하였다. 불용물은 여지와 같이 사용했던 회화 용기에 옮겨 건고한 후 다시 회화하였다. 이 회분을 증류수로 적셔 염산 용액 약 $2 \mathrm{~mL}$ 를 가해 증류수 약 $5 \mathrm{~mL}$ 로 희석한 후 수욕 상에서 가온하였다. 여과한 액을 앞의 $100 \mathrm{~mL}$ 메스플라스크에 채워 증류수를 가하여 $100 \mathrm{~mL}$ 로 정 용하고 시험용액으로 사용하였다. ICP-OES(Optima 7000DV, Perkin Elmer, Waltham, MA, USA)를 이용하여 무기질 함량 을 측정하고, 이때 표준용액으로 얻은 각각의 검량선을 이용 하여 정량하였다. ICP-OES를 이용한 기기분석 조건은 Table 1 과 같다.

무기질 함량 $(\mathrm{mg} / 100 \mathrm{~g})=(\mathrm{C} \times \mathrm{D} \times \mathrm{V}) /(\mathrm{S}) \times(1 / 10)$

$\mathrm{C}$ : 흡광곡선에서 구한 결과값 $(\mathrm{mg} / \mathrm{kg})$

$\mathrm{D}$ : 시험용액의 희석배수

$\mathrm{V}$ : 시험용액의 전량 $(\mathrm{mL})$

$\mathrm{S}$ : 검체의 채취량 $(\mathrm{g})$

\section{옻 발효물의 유리아미노산 정성분석}

MSG 잔존량과 GABA 생성능 비교를 위한 thin-layer chromatography(TLC) 분석을 수행하였으며, 표준물질로 $0.5 \%$ $\mathrm{MSG}$ 와 $0.5 \% \mathrm{GABA}$ 용액을 사용하였다. 전개 용매는 n-butyl alcohol : acetic acid glacial : distilled water를 $3: 1: 1(\mathrm{v} / \mathrm{v})$ 의 비율로 혼합하여 사각 chamber $(30 \times 25 \times 10 \mathrm{~cm})$ 에 넣고 실 온에서 4시간 이상 포화시켰다. 발효물은 증류수로 3-5배 희 석한 후 각각 시료와 standard 용액을 silica gel TLC plate $(10 \times 20 \mathrm{~cm})$ 의 아래에서 $15 \mathrm{~mm}$ 되는 위치에 $2 \mu \mathrm{L}$ 를 점

Table 1. Condition of IOP-OES equipment analysis for inorganic content measurement

\begin{tabular}{ccc}
\hline Instrument & ICP-OES (Optima $7000 \mathrm{DV})$ \\
\hline \multirow{2}{*}{ Gas } & Plasma gas & Liquid argon \\
& Shear gas & Air \\
\hline Gas flows (L/min) & Plasma & 15 \\
& Auxiliary & 0.2 \\
RF power & Nebulizer & 0.6 \\
Pump flow rate (mL/min) & \multicolumn{2}{c}{1,500} \\
Spray chamber type & Cyclonic type \\
Plasma view & Radial / axial \\
\hline
\end{tabular}


적 하였고, 간격은 $10-20 \mathrm{~mm}$ 를 유지하였다. 점적 후 $\mathrm{TLC}$ plate의 sample을 건조시킨 다음, 사각 chamber에서 전개한 후 TLC plate는 $105^{\circ} \mathrm{C}$ 건조기에서 건조하였다. 건조한 TLC plate에 발색시약인 $0.2 \%$ ninhydrin 용액을 뿌리고, $100^{\circ} \mathrm{C}$ 건 조기에서 5-10분 동안 발색시킨 후 발효물의 MSG와 GABA spot을 확인하여 정성 분석하였다.

\section{옻 발효물의 유리아미노산 정량분석}

발효물의 유리아미노산 glutamic acid와 GABA 정량분석 을 위해서 HPLC분석을 수행하였다. 발효물 $1 \mathrm{~g}$ 를 취하여 여 과지로 여과한 후 유도체화를 위해 $10 \mu \mathrm{L}$ 를 취하여 Borate Buffer $70 \mu \mathrm{L}$ 와 ACCQ-Fluor Reagent(Waters Co., Ltd., Milford, MA, USA) $20 \mu \mathrm{L}$ 를 넣어 10초간 잘 혼합한 후 1 분 방치하고, $55^{\circ} \mathrm{C}$ oven에서 10 분간 가열 후 방냉하여 분석하였 다. 이때 HPLC(Waters 2475, Waters Co., Ltd.)를 사용하여 측정하였으며, $\mathrm{ACCQ} \cdot \mathrm{Taq}^{\mathrm{TM}}(3.9 \times 150 \mathrm{~mm})$ column을 사용 하였다. 또한. 검출기는 Fluorescence(excitation wavelength는 $250 \mathrm{~nm}$, emission wavelength는 $395 \mathrm{~nm}$ )를 이용하고, mobile phase(A: waters AccQ Taq Eluent A, B: acetonitrile, $\mathrm{C}$ : tertiary distilled water)로 유속 $1.0 \mathrm{~mL} / \mathrm{min}$ 의 속 도로 흘려주었으며, 용매조건은 Table 2와 같다. 표준물질은 증류수에 녹여 각 단계별로 희석하여 작성한 표준 검량선을 이용하여 함량을 계산하였다.

$$
\begin{aligned}
& \text { 함량 }(\%)=(\mathrm{S} \times \mathrm{V} \times \mathrm{D} \times 100) /(\mathrm{W} \times 1,000 \times 1,000) \\
& \text { 이때 } \mathrm{S} \text { 는 시험용액의 농도 }(\mu \mathrm{g} / \mathrm{mL}), \mathrm{V} \text { 는 시험용액의 양 }
\end{aligned}
$$

Table 2. Elution profile for the analysis of free amino acids

\begin{tabular}{cccc}
\hline Time & $\mathrm{A}^{1)}$ & $\mathrm{B}$ & $\mathrm{C}$ \\
\hline & 100 & 0 & 0 \\
0.5 & 99.5 & 0.5 & 0 \\
10.0 & 96.5 & 3.5 & 0 \\
15.0 & 96 & 4 & 0 \\
18.0 & 96 & 4 & 0 \\
19.0 & 91 & 9 & 0 \\
29.5 & 83 & 17 & 0 \\
40.0 & 0 & 50 & 50 \\
450 & 100 & 0 & 0 \\
55.0 & 100 & 0 & 0 \\
\hline
\end{tabular}

${ }^{1)}$ A, Waters AccQ Taq Eluent A: DW = 1:10 (90:900); B, acetonitrile (ACN); C, pure water.
$(\mathrm{mL}), \mathrm{D}$ 는 희석배수, 그리고 $\mathrm{W}$ 는 채취한 검체량 $(\mathrm{g})$ 이다.

\section{통계처리}

실험 결과는 Statistical Package for the Social Science (SPSS, Version 25.0, SPSS Inc., IBM, Armonk, NY, USA) 를 이용하여 평균과 표준편차 $(m e a n \pm \mathrm{SD})$ 를 구하였으며, 각 집단 간 평균치 차이를 검증하기 위하여 one way-ANOVA 및 Duncan's test를 적용하였다. 결과에 대한 검증은 $\mathrm{p}<0.05$ 수준에서 검증하였다.

\section{결과 및 고찰}

\section{옻나무 추출물의 이화학적 성분 분석}

냉동보관된 옻나무 추출물(T. vernicifluum extract, TVE) 은 상온에서 해동시킨 후 사용하였으며, 발효 전 옻나무 추출 물은 $\mathrm{pH} 5.58,0.05 \%$ acidity를 나타내었으며, 고형분과 환원 당 함량은 각각 $0.99 \pm 0.01 \%, 0.55 \pm 0.01 \mathrm{mg} / \mathrm{g}$ 을 함유하였다. 옻나무 추출액을 $121^{\circ} \mathrm{C}$ 에서 15 분간 멸균하여 발효에 사용하 였다.

\section{옻나무 추출물의 무기질 함량 분석}

무기질은 미생물 생육의 필수영양소로서 효소 활성에 조 효소로 작용하면서 미생물의 생육에 요구되는 종류와 함량이 다르다(Landeweert 등, 2001). 옻나무 추출물의 무기질 함량 을 측정한 결과, 각각 $\mathrm{Na} 2.84 \mathrm{mg} / 100 \mathrm{~g}, \mathrm{Ca} 5.27 \mathrm{mg} / 100$ g, K $17.78 \mathrm{mg} / 100$ g, Fe $0.12 \mathrm{mg} / 100$ g, P $3.19 \mathrm{mg} / 100 \mathrm{~g}$, $\mathrm{Mg} 3.54 \mathrm{mg} / 100 \mathrm{~g}, \mathrm{Mn} 0.04 \mathrm{mg} / 100 \mathrm{~g}$ 이었으며, 이중 $\mathrm{K}$ 의 경우 흔히 한약재로 사용되어지는 황칠나무 추출물의 K 2.38 $\mathrm{mg} / 100 \mathrm{~g}$ 에 비해 5 배 가량 높은 함량을 나타내고 있다(Choi, 2016). 또한, 헛개나무 추출물의 무기질 함량 분석에서 $\mathrm{K}$ $8.98 \mathrm{mg} / 100 \mathrm{~g}, \mathrm{P} 5.04 \mathrm{mg} / 100 \mathrm{~g}$ (Yoon과 Lee, 2019) 과 비교 하여도 높은 함량을 나타내었다. 이는 옻나무 추출물이 발효 미생물의 생육을 위한 다양한 무기질을 함유하는 것으로 판 단되었다.

\section{유당 첨가 농도에 따른 혼합발효 특성 비교}

1 차 효모발효를 위해서 옻나무 추출물 $15 \%$ 에 $5 \%$ sucrose, $1 \%$ yeast extract를 첨가한 후 $30^{\circ} \mathrm{C}$ 배양기에서 2 일간 1 차 정 치배양을 진행하였다. 1차 효모발효물의 이화학적 특성 및 생균수를 분석 한 결과는 Table 3 에서 나타내었다. 2 차 젖산 균 발효시에 발효성 당의 농도를 최적화하기 위해서 유당의 첨가에 따른 혼합 발효물의 이화학적 특성 및 생균수를 분석 한 결과는 Table 4에서 나타내었다.

옻나무 추출물을 이용한 1차 효모발효는 sucrose, yeast 
Table 3. Changes in pH, acidity and viable cell count of Toxicodendron vernicifluum extract fermented by $S$. cerevisiae

\begin{tabular}{ccccc}
\hline $\begin{array}{c}\text { Fermentation } \\
\text { strain }\end{array}$ & $1^{\text {st }} \begin{array}{c}\text { Fermentation period } \\
\text { (days) }\end{array}$ & $\mathrm{pH}$ & Acidity (\%) & $\begin{array}{c}\text { Viable cell count } \\
(S . \text { cerevisiae, log CFU/mL) }\end{array}$ \\
\hline & 0 & $5.13 \pm 0.08^{\mathrm{al})}$ & $0.21 \pm 0.01^{\mathrm{a}}$ & $5.38 \pm 0.04^{\mathrm{b}}$ \\
Yeast & 1 & $4.39 \pm 0.02^{\mathrm{b}}$ & $0.25 \pm 0.04^{\mathrm{a}}$ & $7.36 \pm 0.10^{\mathrm{a}}$ \\
& 2 & $4.56 \pm 0.04^{\mathrm{c}}$ & $0.20 \pm 0.03^{\mathrm{a}}$ & $7.37 \pm 0.10^{\mathrm{a}}$ \\
\hline
\end{tabular}

${ }^{1)}$ Each value is a mean \pm SD $(n=3)$. Different letters in the same fermentation period mean significant difference by Duncan's multiple range test ( $<<0.05$ ).

Table 4. Changes in $\mathrm{pH}$, acidity and viable cell count of Toxicodendron vernicifluum extract co-fermented by $S$. cerevisiae and $L$. plantarum according to lactose concentration

\begin{tabular}{|c|c|c|c|c|}
\hline Lactose content $(\%)$ & $\begin{array}{l}2^{\text {nd }} \text { Fermentation period } \\
\text { (days) }\end{array}$ & $\mathrm{pH}$ & Acidity (\%) & $\begin{array}{c}\text { Viable cell count } \\
\text { (L. plantarum, log CFU } / \mathrm{mL})\end{array}$ \\
\hline \multirow{5}{*}{0} & 0 & $4.56 \pm 0.04^{\mathrm{d} 1)}$ & $0.20 \pm 0.03^{\mathrm{d}}$ & $7.44 \pm 0.04^{b}$ \\
\hline & 1 & $5.93 \pm 0.03^{\mathrm{b}}$ & $0.24 \pm 0.06^{\mathrm{c}}$ & $7.75 \pm 0.32^{\mathrm{a}}$ \\
\hline & 3 & $6.09 \pm 0.02^{\mathrm{c}}$ & $0.19 \pm 0.01^{\mathrm{b}}$ & $8.25 \pm 0.017^{\mathrm{a}}$ \\
\hline & 5 & $6.43 \pm 0.04^{\mathrm{a}}$ & $0.15 \pm 0.01^{\mathrm{a}}$ & $8.01 \pm 0.18^{\mathrm{a}}$ \\
\hline & 7 & $6.65 \pm 0.00^{\mathrm{bc}}$ & $0.12 \pm 0.00^{\mathrm{a}}$ & $7.88 \pm 0.16^{\mathrm{a}}$ \\
\hline \multirow{5}{*}{2.5} & 0 & $4.56 \pm 0.04^{\mathrm{e}}$ & $0.13 \pm 0.12^{\mathrm{d}}$ & $7.44 \pm 0.04^{\mathrm{c}}$ \\
\hline & 1 & $4.97 \pm 0.00^{\mathrm{a}}$ & $0.93 \pm 0.04^{c}$ & $9.20 \pm 0.10^{\mathrm{ab}}$ \\
\hline & 3 & $4.81 \pm 0.01^{\mathrm{d}}$ & $1.21 \pm 0.10^{\mathrm{a}}$ & $9.64 \pm 0.68^{\mathrm{a}}$ \\
\hline & 5 & $5.02 \pm 0.01^{\mathrm{c}}$ & $0.82 \pm 0.03^{\mathrm{bc}}$ & $9.27 \pm 0.02^{\mathrm{b}}$ \\
\hline & 7 & $5.12 \pm 0.00^{\mathrm{b}}$ & $0.66 \pm 0.06^{\mathrm{ab}}$ & $9.04 \pm 0.34^{\mathrm{b}}$ \\
\hline \multirow{5}{*}{5.0} & 0 & $4.56 \pm 0.04^{\mathrm{c}}$ & $0.13 \pm 0.12^{\mathrm{d}}$ & $7.44 \pm 0.04^{\mathrm{c}}$ \\
\hline & 1 & $4.93 \pm 0.01^{\mathrm{a}}$ & $1.01 \pm 0.01^{\mathrm{c}}$ & $9.16 \pm 0.04^{\mathrm{a}}$ \\
\hline & 3 & $4.77 \pm 0.01^{\mathrm{b}}$ & $1.45 \pm 0.30^{\mathrm{a}}$ & $8.79 \pm 0.32^{\mathrm{a}}$ \\
\hline & 5 & $4.96 \pm 0.00^{\mathrm{b}}$ & $0.97 \pm 0.01^{\mathrm{bc}}$ & $8.43 \pm 0.40^{\mathrm{b}}$ \\
\hline & 7 & $5.03 \pm 0.01^{\mathrm{b}}$ & $0.85 \pm 0.01^{\mathrm{c}}$ & $9.09 \pm 0.31^{\mathrm{a}}$ \\
\hline
\end{tabular}

${ }^{1)}$ Each value is a mean $\pm \mathrm{SD}(\mathrm{n}=3)$. Different letters in the same fermentation period mean significant difference by Duncan's multiple range test ( $<<0.05$ ).

extract 첨가조건에서 가스 생성을 보이면서 발효 0 일에 $\mathrm{pH}$ 5.03 에서 2 일 차에 $\mathrm{pH} 4.57$ 로 소폭 감소하는 경향을 보였다. 적정 산도는 효모발효 0 일에 $0.09 \%$ 에서 발효 2 일에 $0.10 \%$ 로 유사한 값을 나타내었다. 2차 젖산균 발효과정에서 유당 $2.5 \%, 5.0 \%$ 의 첨가군은 초기 $\mathrm{pH}$ 4.56에서 발효 7일에 각각 $\mathrm{pH} 5.12, \mathrm{pH} 5.03$ 의 낮은 값을 보였으며, 유당 무첨가 군은 $\mathrm{pH} 6.65$ 로 증가하였다. 이때 유당이 첨가된 발효물의 $\mathrm{pH}$ 는 발효 7일 동안 완만하게 증가하면서 산성 조건을 유지하였다.

2차 젖산발효에는 유당 첨가에 의해서 발효 3 일까지 산도 가 크게 증가하였으며, 발효 후반에는 약간 감소하는 경향을 보였다. 유당 $2.5 \%$ 첨가시에 발효물의 초기 산도는 $0.13 \%$ 에
서 발효 3일에 $1.21 \%$ 로 증가하여 가장 높은 산도값을 나타낸 후 발효 7일에는 $0.66 \%$ 로 크게 감소하였다. 또한, 유당 $5.0 \%$ 첨가 경우에 발효 초기 $0.13 \%$ 산도에서 발효 3 일에 $1.45 \%$ 로 증가한 후 발효 7 일에는 산도 $0.85 \%$ 로 감소하였다. 이는 젖 산균 발효 7일 동안 발효물의 $\mathrm{pH}$ 증가와 함께 산도가 감소하 는 경향을 보이면서 정상적인 젖산균 발효의 양상과는 차이 가 있었다. 2차 젖산균 발효에서 첨가하는 전구물질인 $\mathrm{MSG}$ 를 이용하여 기능성물질 $\mathrm{GABA}$ 를 생산하는 과정에서 proton 이 소비되면서 $\mathrm{pH}$ 증가와 산도 감소한다는 연구(Feehily and Karatzas, 2012)와 유사한 현상을 보였다.

1차 효모 발효에서 생균수는 $5.95 \log \mathrm{CFU} / \mathrm{mL}$ 에서 7.63 
$\log \mathrm{CFU} / \mathrm{mL}$ 로 증가하였으며, 2차 젖산균 혼합 발효과정에 서 유당을 첨가하지 않은 경우 발효 7일 차에 효모 생균수가 $7.22 \log \mathrm{CFU} / \mathrm{mL}$ 로 비교적 높은 값을 보였다. 이때 2차 혼 합발효시에 젖산균은 발효 0 일 차에 $7.44 \log \mathrm{CFU} / \mathrm{mL}$ 에서 발효 7일에 $7.88 \log \mathrm{CFU} / \mathrm{mL}$ 로 소폭 증가하였다.

반면에 유당 $2.5 \%, 5.0 \%$ 를 첨가 경우 2 차 젖산균 혼합 발 효물에서 효모 생균수는 크게 감소하면서 각각 $5.68 \mathrm{log}$ $\mathrm{CFU} / \mathrm{mL}, 5.40 \log \mathrm{CFU} / \mathrm{mL}$ 로 측정되었다. 유당 $2.5 \%, 5 \%$ 첨가한 2차 젖산균 발효물은 발효 1 일에 $9.1 \log \mathrm{CFU} / \mathrm{mL}$ 이 상으로 크게 증가한 후 발효 7일에 소폭 감소하면서 $9.0 \mathrm{log}$ $\mathrm{CFU} / \mathrm{mL}$ 정도로 나타났다. 이는 유당 첨가로 젖산균의 생육 증가에 따른 젖산 생성으로 효모의 생육환경에 영향을 미친 다는 것으로 판단되었다. 효모, 젖산균 혼합 발효시에 발효성 당으로 유당을 첨가한 발효물에서 GABA 생성을 분석한 결 과, $2.5 \%$ 유당을 첨가 경우에 발효 5 일에 전구물질 $\mathrm{MSG}$ 가 모두 소진되면서 $\mathrm{GABA}$ 로 전환되었다(Fig. 1). 결론적으로 옻나무 추출물의 효모 젖산균 혼합 발효과정에서 발효성 당 으로 유당 $2.5 \%$ 의 첨가는 2 차 젖산균의 생육을 도와주면서 유기산 생성과 젖산균의 생균수를 증가시키며, 동시에 효과 적으로 $\mathrm{GABA}$ 를 생합성하는 것으로 나타나서 $\mathrm{GABA}$ 생성 의 최적 조건으로 결정하였다.

\section{MSG 농도에 따른 $\mathrm{pH}$ 및 적정산도 변화}

옻나무 추출물의 효모와 젖산 혼합발효를 통한 $\mathrm{GABA}$ 생 산 최적화하기 위해서 유당 $2.5 \%$ 를 첨가하여 $\mathrm{MSG}$ 의 첨가 농도를 달리하여 $\mathrm{pH}$ 와 적정 산도를 측정하였다.

1 차 효모발효에서는 옻 발효물의 초기 $\mathrm{pH} 5.03$ 에서 발효 2 일 차 $\mathrm{pH}$ 가 소폭 감소하면서 $\mathrm{pH} 4.57$ 을 나타내었다. 2차 젖산 발효시에 $\mathrm{MSG}$ 를 무첨가의 경우 발효물의 $\mathrm{pH}$ 는 초기
6.15 에서 발효가 진행되면서 지속적으로 감소하여 발효 7일 에 $\mathrm{pH} 3.42$ 를 나타내었다. 1차 효모 발효물에 $\mathrm{MSG}$ 를 첨가 하여 2차 젖산균 발효를 수행하는 경우에 $\mathrm{pH}$ 는 일부 상승하 는 경향을 보였다. MSG $2.5 \%$ 첨가한 2차 젖산 발효물의 초 기 $\mathrm{pH}$ 6.64에서 발효 3일에 $\mathrm{pH}$ 4.6으로 감소한 후 발효 7일 에 발효물의 $\mathrm{pH}$ 는 소폭 상승하면서 $\mathrm{pH} 4.65$ 를 나타내었다. $\mathrm{MSG}$ 농도를 5\% 첨가한 2차 젖산균 발효물의 초기 $\mathrm{pH} 6.62$ 에서 발효 3일에 $\mathrm{pH}$ 4.80으로 감소한 후 발효 7일에 약간 증가하면서 $\mathrm{pH} 5.04$ 를 나타내었다. 이는 GABA생산의 전구 물질로서 $\mathrm{MSG}$ 를 최대 $5 \%$ 수준으로 첨가할 때 젖산 발효 초 반에 젖산 생성에 의해 발효물의 $\mathrm{pH}$ 가 감소하지만, 발효가 진행되면서 발효물의 $\mathrm{pH}$ 가 증가하는 경향을 보였다(Fig. 2).

적정 산도는 1 차 효모발효 초기와 발효 2 일에 각각 $0.09 \%$, $0.10 \%$ 로 큰 변화는 없었다. $\mathrm{MSG}$ 무첨가 경우에 2 차 젖산발 효물의 산도는 초기 $0.07 \%$ 에서 발효 7일 동안에 완만하게 증 가되면서 발효 7 일에 산도 $0.53 \%$ 를 나타내었다. MSG $2.5 \%$ 를 첨가한 2 차 젖산발효물의 초기 산도는 $0.06 \%$ 에서 발효 3 일에 $0.72 \%$ 로 가장 높은값을 보인 후에 발효 7 일에 $0.66 \%$ 로 감소하였다. 또한, MSG 5\%를 첨가한 2차 젖산발효물의 산 도는 초기 $0.13 \%$ 에서 발효 3 일에 $0.92 \%$ 로 가장 높은 값을 보인 후에 발효 7 일에 산도 $0.61 \%$ 로 감소하였다(Fig. 3). 일 반적인 젖산발효에 의한 발효물은 $\mathrm{pH}$ 감소와 산도의 증가를 보이는 결과와 다른 경향을 보인 것은 젖산균 발효과정에서 첨가되는 전구물질 $\mathrm{MSG}$ 의 역할에 기인하는 것으로 판단되 었다. 젖산균에 의한 GABA 생산에서 기질인 glutamic acid 는 glutamate decarboxylase 효소에 의해서 탈탄산되어 GABA가 생성된다. 이때 효소에 의한 생물전환 과정에서 proton을 소진시키면서 발효물의 산도가 감소하는 것을 보고 하였다(Cui 등, 2020; Feehily와 Karatzas, 2012).

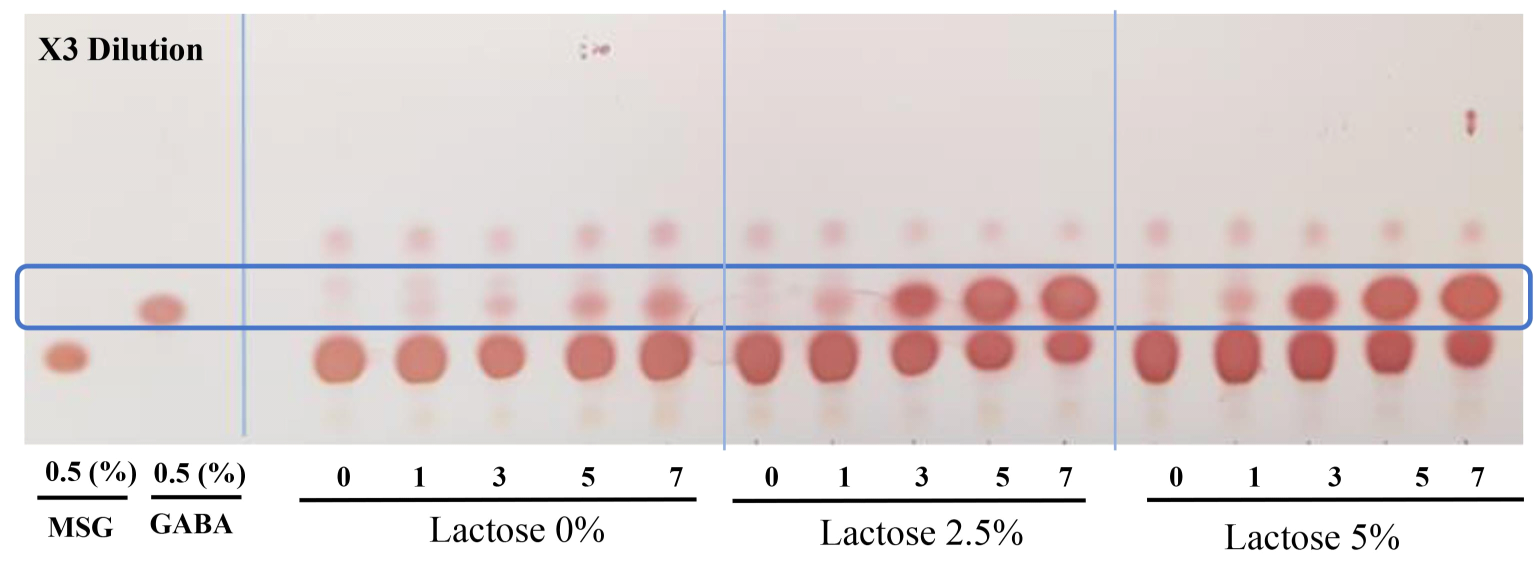

Fig. 1. Effect of lactose content on the GABA production of Toxicodendron vernicifluum extract co-fermented by $S$. cerevisiae and $L$. plantarum. 


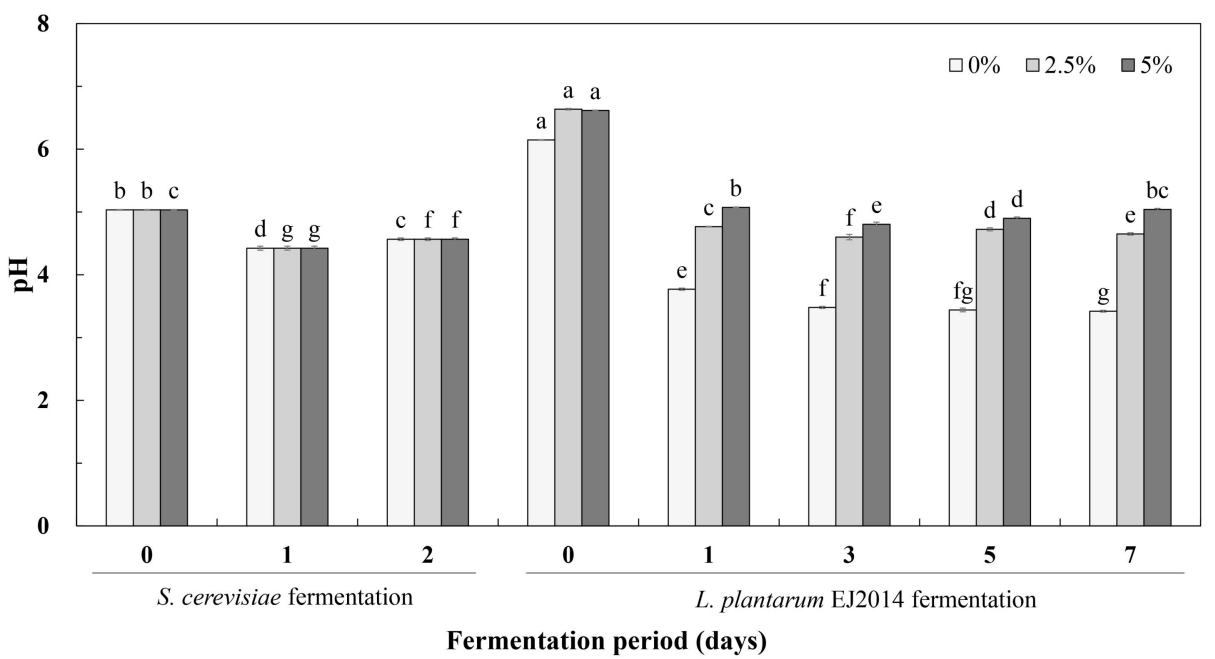

Fig. 2. Changes in pH of Toxicodendron vernicifluum extract co-fermented by $S$. cerevisiae and $L$. plantarum according to MSG concentration.

Each value is a mean $\pm \mathrm{SD}(\mathrm{n}=3)$. Different letters in the same fermentation period mean significant difference by Duncan's multiple range test $(\mathrm{p}<0.05)$

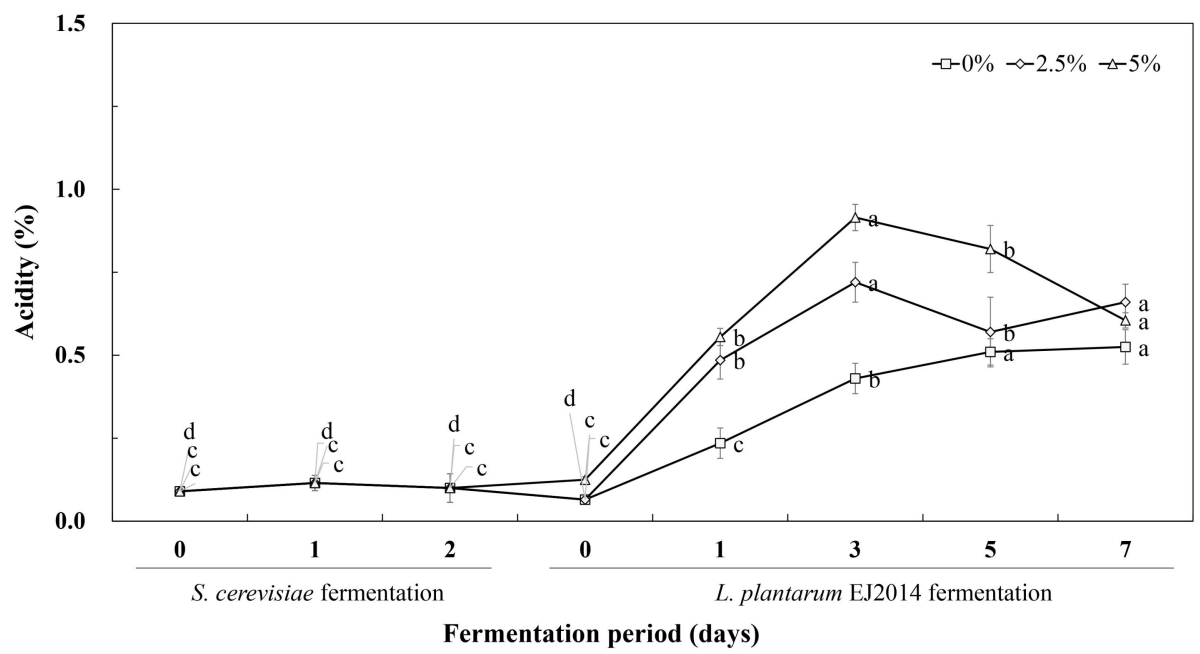

Fig. 3. Changes in acidity of Toxicodendron vernicifluum extract co-fermented by $S$. cerevisiae and $L$. plantarum according to MSG concentration.

Each value is a mean $\pm \mathrm{SD}(\mathrm{n}=3)$. Different letters in the same fermentation period mean significant difference by Duncan's multiple range test $(\mathrm{p}<0.05)$.

\section{MSG 농도에 따른 생균수 변화}

옻나무 추출물의 효모와 젖산 혼합발효를 통한 GABA 생 산 최적화하기 위해 $\mathrm{MSG}$ 의 첨가 비율을 달리하여 진행한 발 효물의 생균수를 측정한 결과를 Fig. 3에 나타내었다.

1 차 효모발효에서는 발효 초기와 발효 2일에 생균수는 각 각 $5.95 \log \mathrm{CFU} / \mathrm{mL}, 7.63 \log \mathrm{CFU} / \mathrm{mL}$ 로 측정되었다. 2차 젖산발효과정에서 전구물질로서 $\mathrm{MSG}$ 의 첨가 비율에 따른 생균슈를 측정한 결과는 Fig. 3 에 나타내었다. 2차 젖산발효
가 진행된 1 일 차에는 $\mathrm{MSG}$ 를 $0 \%, 2.5 \%, 5 \%$ 로 첨가한 발효 물의 효모 생육은 $7.16 \log \mathrm{CFU} / \mathrm{mL}, 6.84 \log \mathrm{CFU} / \mathrm{mL}, 7.22$ $\log \mathrm{CFU} / \mathrm{mL}$ 로 비슷한 값을 보였다. 2 차 젖산발효 3 일 차의 효모 생육은 $6.3 \log \mathrm{CFU} / \mathrm{mL}, 6.7 \log \mathrm{CFU} / \mathrm{mL}, 5.7 \log$ $\mathrm{CFU} / \mathrm{mL}$ 로 효모의 생균수는 점차 감소하는 경향을 보였다. 발효 7일 차에 MSG 5\% 첨가의 경우에 비교적 높은 생균수 를 보이면서 MSG $0 \%, 2.5 \%, 5 \%$ 는 각각 $4.85 \log \mathrm{CFU} / \mathrm{mL}$, $4.85 \log \mathrm{CFU} / \mathrm{mL}, 5.29 \log \mathrm{CFU} / \mathrm{mL}$ 의 효모 생균수를 나타 
내었다(Fig. 4).

2차 젖산발효가 진행됨에 따라 발효 초기에 1차 효모 발효 물에서 젖산균은 $7.44 \log \mathrm{CFU} / \mathrm{mL}$ 로 생균수로 접종되었으 며, 젖산 발효가 진행됨에 따라 젖산균의 생육에 차이를 보였 다. 2 차 젖산발효 1 일 차에 $\mathrm{MSG} 0 \%, 2.5 \%, 5 \%$ 첨가한 발효 물의 생균수는 각각 $8.82 \log \mathrm{CFU} / \mathrm{mL}, 9.09 \log \mathrm{CFU} / \mathrm{mL}$, $9.34 \log \mathrm{CFU} / \mathrm{mL}$ 로 $\mathrm{MSG}$ 의 농도가 높을수록 젖산균의 생균 수가 높은 것으로 나타났다. 발효 3일 이후에는 생균수가 감 소하는 경향을 보였으며, 2차 젖산발효 7일에는 $\mathrm{MSG} 0 \%$, $2.5 \%, 5 \%$ 첨가한 경우에 발효물의 젖산균 생균수는 각각 $7.46 \log \mathrm{CFU} / \mathrm{mL}, 7.81 \log \mathrm{CFU} / \mathrm{mL}, 8.19 \log \mathrm{CFU} / \mathrm{mL}$ 로 나타났다. 결론적으로 2 차 젖산균 발효시에 첨가되는 중성
아미노산인 $\mathrm{MSG}$ 는 젖산균의 생육과 생존에 기여하는 것으 로 판단되며, $5 \% \mathrm{MSG}$ 첨가조건에서 가장 높은 생균수를 보 였다(Fig. 4).

\section{MSG 농도 최적 조건의 환원당 변화}

$\mathrm{MSG}$ 첨가농도 최적 조건에서 젖산발효에 따른 환원당 변 화는 Fig. 5 와 같다. 옻 추출액의 환원당은 $0.45 \%$ 에서 1 차 효모발효 초기에 옻나무 추출물 혼합 배양액의 환원당은 $0.1 \%$ 에서 발효 2 일에 $0.05 \%$ 로 소폭 감소하는 경향을 보였 다. 2차 젖산발효과정에서 $2.5 \% \mathrm{MSG}$ 와 $2.5 \%$ lactose가 첨 가되면서 2차 젖산 발효 초기에 $2.99 \%$ 환원당에서 발효가 진 행되면서 감소하여 발효 5 일, 7 일에 각각 환원당 $1.0 \%$,

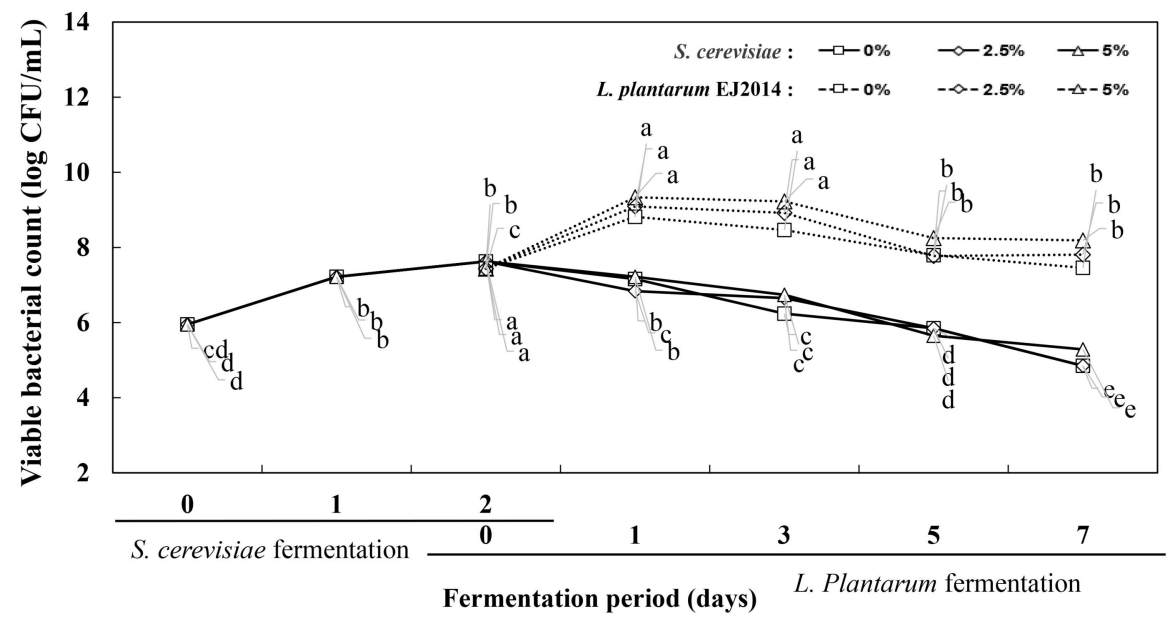

Fig. 4. Changes in viable cell count of Toxicodendron vernicifluum extract co-fermented by $S$. cerevisiae and $L$. plantarum according to MSG concentration.

Each value is a mean $\pm \mathrm{SD}(\mathrm{n}=3)$. Different letters in the same fermentation period mean significant difference by Duncan's multiple range test $(\mathrm{p}<0.05)$.

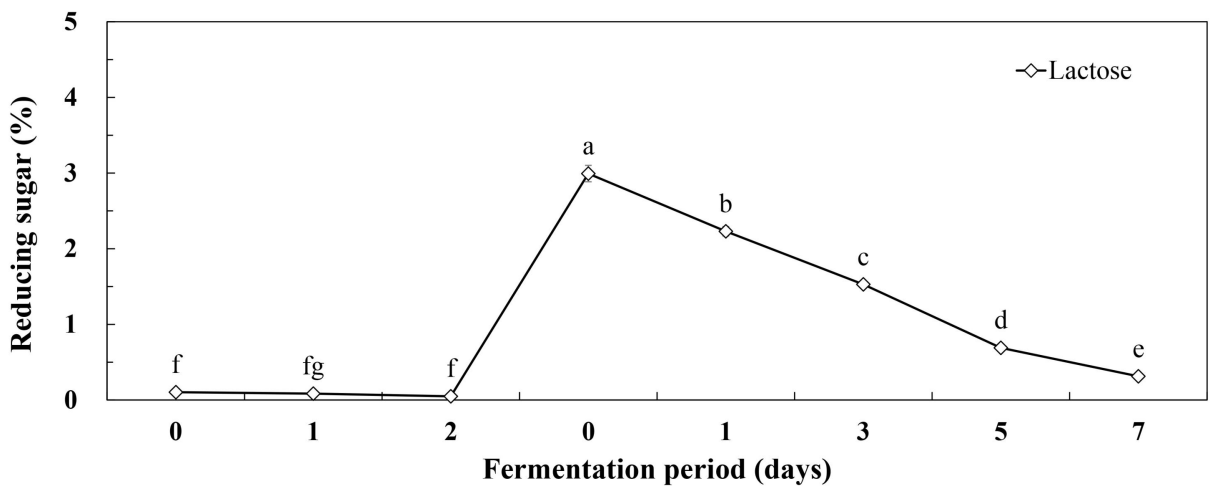

Fig. 5. Changes in reducing sugar content of Toxicodendron vernicifluum extract co-fermented by $S$. cerevisiae and $L$. plantarum. Each value is a mean $\pm \mathrm{SD}(\mathrm{n}=3)$. Different letters in the same fermentation period mean significant difference by Duncan's multiple range test $(\mathrm{p}<0.05)$. 
$0.31 \%$ 를 나타내었다. 2 차 젖산균에 의한 혼합발효가 진행될 수록 유당이 급격하게 감소하여 환원당이 소진된 것을 확인 할 수 있었다. 따라서 효모, 젖산균 혼합발효과정에서 유당 발효능이 결여된 효모보다는 젖산균의 유당 발효를 통해서 젖산 등의 대사산물 생산 및 전구물질인 $\mathrm{MSG}$ 를 이용한 $\mathrm{GABA}$ 생산을 기대할 수 있었다. 사과즙을 이용한 젖산균에 의한 GABA 생산에서 발효배지의 발효성 당 함량이 높은 경 우에 GABA 전환이 미비한 연구결과를 얻었으며, 이를 바탕 으로 2차 젖산균 발효를 통한 $\mathrm{GABA}$ 생산에서 발효 5 일 이 후 발효성 당이 $1.0 \%$ 정도를 유지하는 것이 바람직하다고 판 단되었다(Lee 등, 2020).

\section{MSG 농도에 따른 GABA 함량 변화}

옻나무 추출물의 효모와 젖산 혼합발효를 통한 GABA 생 성능을 확인하기 위해 TLC를 이용하여 정성분석을 진행하 였다. 이는 선행연구에서 효모를 이용하여 1차 발효를 수행 한 후 2차 젖산균 발효를 수행하는 것이 효과적으로 $\mathrm{GABA}$ 생산이 가능하였다. 또한 다른 연구(Kim, 2013; Masuda 등, 2008)에 따르면 TLC상 효모가 GABA 생산능력이 있는 것으 로 나타났다. TLC 분석결과는 Fig. 6 과 같다. $\mathrm{MSG}$ 를 $0 \%$ 첨 가한 발효물은 GABA가 전혀 생성되지 않았으며 MSG $2.5 \%$ 첨가한 발효물의 발효 1 일부터 $\mathrm{GABA}$ 전환이 시작되어 $\mathrm{MSG}$ 소진과 $\mathrm{GABA}$ 전환이 가장 빠른 것으로 나타났으며, 발효 7일에 전구물질 $\mathrm{MSG}$ 가 모두 소진되고 $\mathrm{GABA}$ 를 생성 하였다. 또한, $\mathrm{MSG} 5 \%$ 첨가한 발효물의 경우 7 일 차에는 $\mathrm{MSG}$ 의 소진이 덜 되었지만 $\mathrm{GABA}$ 생성량이 더 높은 것으 로 나타났다. 결론적으로 옻나무 추출물의 효모-젖산 혼합발 효에서 $2.5 \% \mathrm{MSG}$ 가 첨가된 조건이 $\mathrm{GABA}$ 로의 전환능이 더욱 뛰어난 것으로 나타나서 최적조건으로 판단되었다. 본 연구에서는 2 차 발효 3 일차에 $\mathrm{MSG}$ 의 $\mathrm{GABA}$ 로의 전환이 시
작되어 7일차에 전부 전환된 것을 확인할 수 있었다. 이는 유 청을 이용한 혼합발효를 통한 $\mathrm{GABA}$ 의 생산연구(Kim, 2019) 와 늙은 호박의 혼합 발효를 통한 GABA 생산연구(Park, 2017)에서도 혼합발효 3일차부터 GABA가 생산되는 것과 유사한 결과를 보였다.

\section{$\mathrm{HPLC}$ 를 이용한 옻나무 추출물 발효물의 GABA 분석}

옻나무 추출물 발효물의 $\mathrm{GABA}$ 생성의 정량분석을 위해 $\mathrm{HPLC}$ 로 분석을 진행하였다. Glutamic acid 표준용액은 15.7 분에 peak를 나타냈으며, GABA는 23.3분에 peak를 나타내 어 각각의 표준물질에 대한 retention time을 확인하였다(Fig. 7, Fig. 8). 옻나무 추출물의 최적 발효조건인 1 차 효모발효 종료 후 lactose $2.5 \%$ 와 MSG 2.5\%를 추가 발효한 2차 젖산 균 혼합발효물의 분석결과, 2 차 젖산발효 초기에 $2.49 \pm 0.08$ $\mathrm{g} / 100 \mathrm{~g}$ 이었던 glutamic acid는 발효 7일 차에는 모두 소진되 면서 존재하지 않았으며, $\mathrm{GABA}$ 함량은 2차 젖산발효 7일에 $1.85 \pm 0.02 \mathrm{~g} / 100 \mathrm{~g}$ 으로 증가하는 것을 확인할 수 있었다 (Table 5). 따라서 발효 결과 대부분의 glutamic acid가 GABA 로 전환한 것을 확인할 수 있었으며, glutamic acid의 GABA 로의 전환율은 $74.3 \%$ 로 나타났다.

천연소재로 $\mathrm{GABA}$ 는 현미 $100 \mathrm{~g}$ 당 $4-8 \mathrm{mg}$, 발아현미 10-100 mg으로 자연에서 얻을 수 있는 GABA는 제한적이 며, 젖산균을 이용한 발효물에서 $250 \mathrm{mg}$ 이상의 $\mathrm{GABA}$ 를 함유한다는 연구가 보고되었다(Hwang, 2011; Mody 등, 1994; Park, 2012). 울금을 이용한 B. subtilis HA와 L. plantarum $\mathrm{K} 154$ 의 혼합발효에서 $1.78 \% \mathrm{GABA}$ 생산이 보고 되었으며(Lim, 2014), 녹각 추출물을 이용한 L. plantarum EJ2014의 발효에서 1.4\%, Leuconostoc mesenteroides SM와 Lactobacillus plantarum $\mathrm{K} 154$ 균주의 혼합발효에서는 $1.23 \%$ 의 GABA가 생산되었다고 보고되었다(Kwon, 2016; Song,

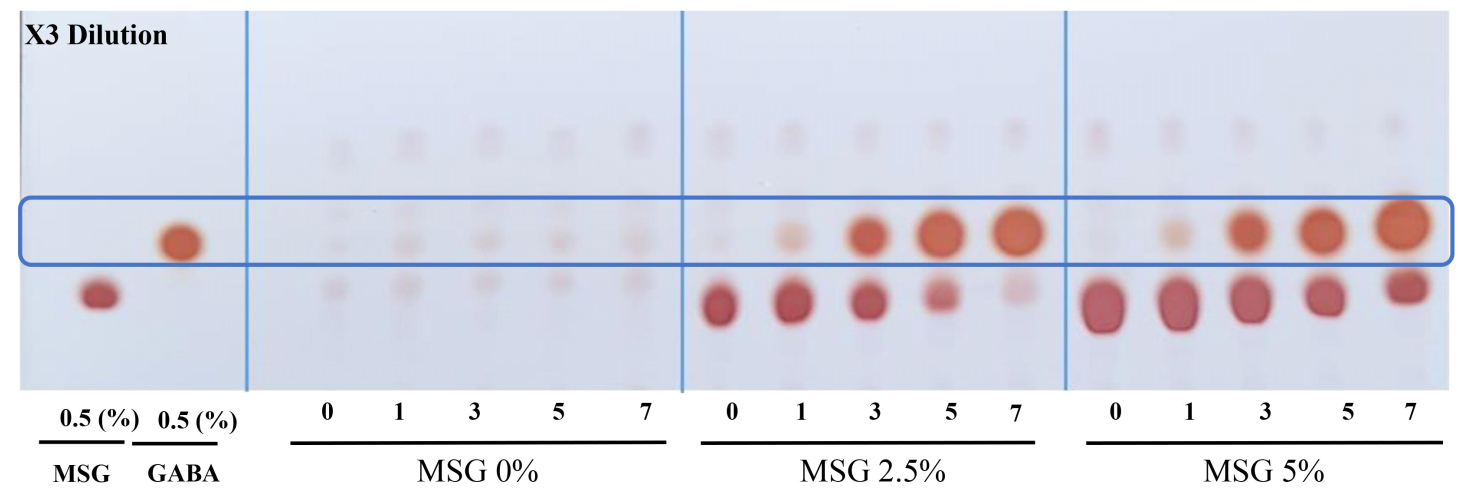

Fig. 6. Effect of MSG content on the GABA production of Toxicodendron vernicifluum extract co-fermented by $S$. cerevisiae and $L$. plantarum. 


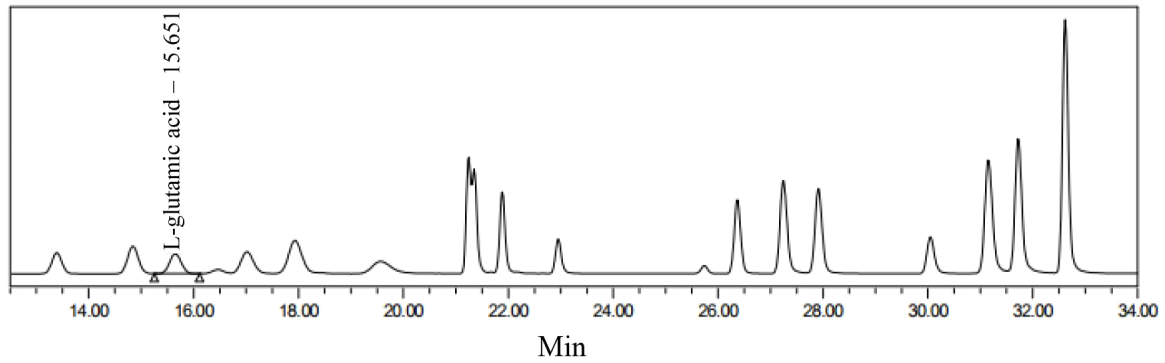

Fig. 7. HPLC chromatogram of L-glutamic acid standard solution.

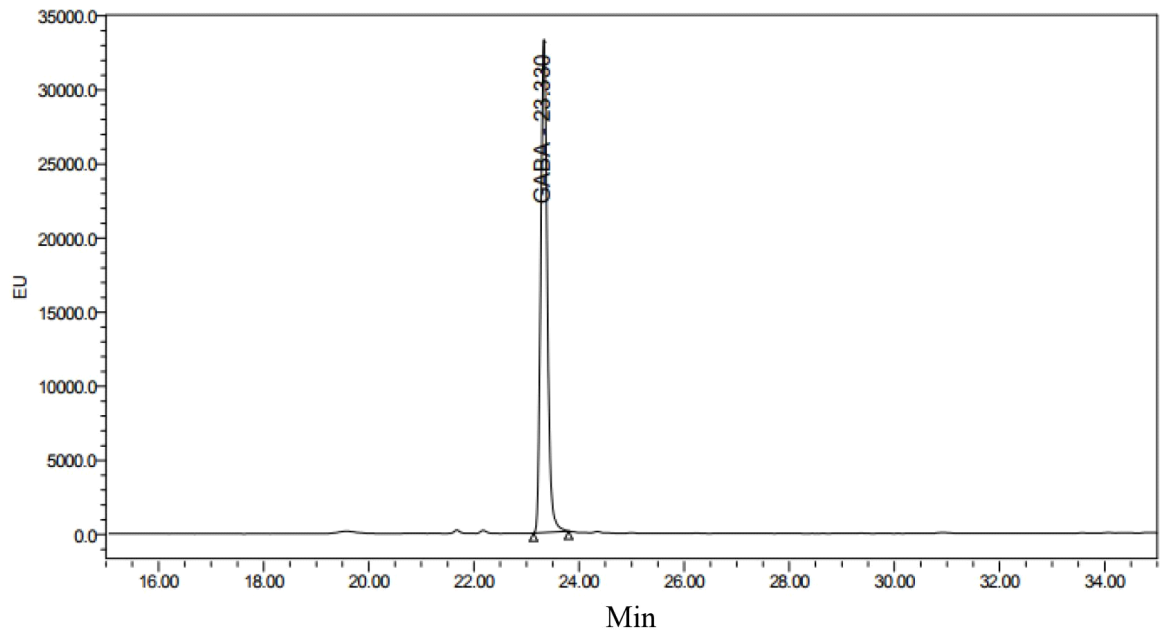

Fig. 8. HPLC chromatogram of GABA standard solution.

Table 5. Free amino acid content of co-fermented TVE anayzed by HPLC

\begin{tabular}{ccc}
\hline \multirow{2}{*}{ Free amino acid } & \multicolumn{2}{c}{ Co-fermentation period (day) } \\
\cline { 2 - 3 } & 0 & 7 \\
\hline Glutamic acid $(\mathrm{g} / 100 \mathrm{~g})$ & $2.49 \pm 0.08^{1)}$ & $0.00 \pm 0.02$ \\
GABA $(\mathrm{g} / 100 \mathrm{~g})$ & $0.03 \pm 0.02$ & $1.85 \pm 0.02$ \\
\hline
\end{tabular}

${ }^{1)}$ Each value is a mean \pm SD $(n=3)$.

2014). 옻나무 추출물의 효모, 젖산균 혼합발효를 통해서 1차 효모배양물에 첨가된 전구물질인 $\mathrm{MSG}$ 가 효과적으로 생물전 환되면서 고농도 $\mathrm{GABA}$ 를 생산할 수 있었다.

\section{요 약}

본 연구에서는 옻나무 추출물을 이용하여 Saccharomyces cerevisiae와 Lactobacillus plantarum EJ2014 균주를 이용하여
$\mathrm{GABA}$ 생성의 최적 조건을 위해 배지의 유당, $\mathrm{MSG}$ 농도 효과 를 분석하였다. 1 차 효모발효를 위해서 멸균시킨 옻나무 추출 액에 sucrose $2.5 \%$ 와 yeast extract $1 \%$ 를 첨가 후 S. cerevisiae starter $1 \%$ 를 접종하여 항온배양기에서 $30^{\circ} \mathrm{C}, 2$ 일간 정치 배양 하였다. 그 후 2차 젖산발효에는 MSG $2.5 \%$ 와 lactose $2.5 \%$ 를 첨가하고 L. plantarum $1 \%$ 를 접종하여 $30^{\circ} \mathrm{C}$ 항온배양기에 서 7일간 정치 배양한 결과, 혼합발효물은 $\mathrm{pH} 4.65$, acidity $0.66 \%$, 생균 수 젖산균 $7.81 \log \mathrm{CFU} / \mathrm{mL}$, 효모 $4.85 \log$ $\mathrm{CFU} / \mathrm{mL}$ 를 나타내었다. 특히, 첨가된 $\mathrm{MSG} 2.5 \%$ 는 모두 소 진되면서 $1.85 \%$ 의 $\mathrm{GABA}$ 를 생산하였다. S. cerevisiae와 $L$. plantarum를 이용한 연속적인 혼합발효를 통해서 GABA 등의 생리활성물질이 강화된 옻나무 추출물 발효물은 고부가가치의 기능성 식품소재로서의 다양한 활용이 기대된다.

\section{Conflict of interests}

The authors declare no potential conflict of interest. 


\section{ORCID}

Hye-Mi Kang https://orcid.org/0000-0001-7978-9224

Sam-Pin Lee https://orcid.org/0000-0001-9413-2482

\section{References}

Bang CS, Hong SH, Suk KT, Kim JB, Han SH, Sung H, Kim EJ, Kim MJ, Kim MY, Baik SK, Kim DJ. Effects of Korean red ginseng (Panax ginseng), urushiol (Rhus vernicifera Stokes), and probiotics (Lactobacillus rhamnosus R0011 and Lactobacillus acidophilus R0052) on the gut-liver axis of alcoholic liver disease. J Ginseng Res, 38, 167-172 (2014)

Braslau R, Rivera F, Lilie E, Cottman M. Urushiol detection using a profluorescent nitroxide. J Org Chem, 78, 238245 (2013)

Carr FJ, Chill D, Maida N. The lactic acid bacteria: A literature survey. Crit Rev Microbiol, 28, 281-370 (2002)

Choi HS, Kim BH, Yeo SH, Jeong ST, Choi JH, Park HS, Kim MK. Physicochemical properties and physiological activities of Rhus verniciflua stem bark cultured with Fomitella fraxinea. Kor J Mycol, 38, 172-178 (2010)

Choi JW. Optimized production of poly- $\gamma$-glutamic acid and $\gamma$-aminobutyric acid from Dendropanax morbifera extracts by Bacillus subtilis and Lactobacillus plantarum. MS Thesis, Keimyung University, Korea, p 15 (2016)

Cui Y, Miao K, Niyaphorn S, Qu X. Production of gamma-aminobutyric acid from lactic acid bacteria: A Systematic Review. Int J Mol Sci, 21, 995 (2020)

Feehily C, Karatzas, KAG. Role of glutamate metabolism in bacterial responses towards acid and other stresses. J Appl Microbiol, 114, 11-24 (2012)

Hwang JM. Selection of superior functionality soybeans and changes of isoflavone and GABA contents according to soymilk lactic acid fermentation conditions. MS Thesis, Andong National University, Korea, p 46 (2011)

Im JS, Kim MO, Hong MS, Kim MS, Cheun CK, Park YE, Cho JH, Cho KS, Chang DC, Choi JG, Lee JN. Effects of salt stress on dry matter, glucose, minerals content and composition in potato (Solanum tuberosum L.). Korean J Environ Agric, 38, 38-46 (2019)

Jeong SJ, Yang HJ, Ryu MS, Seo JW, Jeong DY. Validation of the analytical method for chlorogenic acid in blueberry yeast fermented powder for standardization as a functional health ingredient. J Korean Soc Food Sci Nutr, 48, 1098-1104 (2019)

Jin HY, Moon HJ, Kim SH, Lee SC, Huh CK. Quality characteristics of blended tea with added pan-firing Rhus verniciflua seeds and changes in its antioxidant activity during storage. Korean J Food Sci Technol, 49, 318-323 (2017)

Kim DH, Jeong D, Kang IB, Kim H, Song KY, Seo KH. Dual function of Lactobacillus kefiri DH5 in preventing high-fat-diet-induced obesity: Direct reduction of cholesterol and upregulation of PPAR- $\alpha$ in adipose tissue. Mol Nutr Food Res, 61, 1700252 (2017)

Kim GY. Optimized production of $\gamma$-aminobutyric acid in whey by co-fermentation using yeast, Bacillus subtilis and Lactobacillus plantarum. MS Thesis, Keimyung University, Korea, p 56 (2019)

Kim IW, Shin DH, Jang YS. Antioxidative activity of some antioxidants and emulsifiers in bulk and emulsion systems. Korean J Food Sci Technol, 31, 1077-1083 (1999)

Kim JH. Isolation and characterization of high GABA producing yeast isolated from fermented Bokbunja wine. MS Thesis, Chonbuk National University, Korea, $\mathrm{p}$ 40-48 (2013)

Kim JS. Optimum bioconversion of sodium glutamate to $\gamma$ poly-glutamic acid and $\gamma$-amino-butyric acid by mixed fermentation using lactic acid bacteria and Bacillus subtilis HA. MS Thesis, Keimyung University, Daegu, Korea, p 2-3 (2013)

Kim TH, Lee KM, Kwon KR, Choi SM. A literature study on lacquer poison. J Pharmacopuncture, 5, 159-169 (2002)

Kwon SY. Production of $\gamma$-amino butyric acid (GABA) in old antler fermented by Lactobacillus plantarum and evaluation of bioactive property. MS Thesis, Keimyung University, Korea, p 64 (2016)

Landeweert R, Hoffland E, Finlay RD, Kuyper TW, van Breemen N. Linking plants to rocks: Ectomycorrhizal fungi mobilize nutrients from minerals. Trends Ecol Evol, 16, 248-254 (2001)

Lee MS, Kim JS, Cho SM, Lee SO, Kim SH, Lee HJ. Fermented Rhus verniciflua Stokes extract exerts an 
antihepatic lipogenic effect in oleic-acid-induced HepG2 cells via upregulation of AMP-activated protein kinase. J Agric Food Chem, 63, 7270-7276 (2015)

Lee SP, Park JH, Choi JY, Kim GY, Yoon WK, Heo GM, Yeo GR. Method for manufacturing functional fermented material of apple juice and Auricularia judae by mixed fermentation with yeast and lactic acid bacteria. Korea Patent No.1020734800000 (2020)

Lim HJ, Lim HY, Lee JM, Kim HJ. The anti-inflammatory influence of fermented soy products containing a fermented Rhus verniciflua extract on lipopolysaccharide (LPS)-treated RAW 264.7 cells. Korean J Food Sci Technol, 50, 642-652 (2018)

Lim JS. Optimized production of bioactive compounds from turmeric and roasted soybean mixture by Bacillus subtilis and Lactobacillus plantarum. MS Thesis, Keimyung University, Korea, p 50-51 (2014)

Lim JY. Optimization for the production of roasted wheat bran fortified with mucilage and GABA by mixed fermentation using Bacillus subtilis HA and Lactobacillus plantarum K154. MS Thesis, Keimyung University, Korea, p 1-2 (2013)

Masuda K, Guo XF, Uryu N, Hagiwara T, Watabe S. Isolation of marine yeasts collected from the pacific ocean showing a high production of $\gamma$-aminobutyric acid. Biosci Biotechnol, Biochem, 72, 3265-3272 (2008)

Mody I, De Koninck Y, Otis TS, Soltesz I. Bringing the cleft at GABA synapses in the brain. Trends Neurosci, 17, 517-525 (1994)
Oh NR. Physiological characteristics of Lactobacillus crispatus RMK567 isolated from milk and optimization of GABA producing condition. MS Thesis, Sungkyunkwan University, Korea, p 1-2 (2005)

Park EJ. Optimized production of $\gamma$-aminobutyric acid and bioactive compounds from old pumpkin (Cucurbita moschata) by co-fermentation. MS Thesis, Keimyung University, Korea, p 47-53 (2017)

Park JH. Optimization of $\gamma$-aminobutyric acid production in homogenized hydroponic ginseng by fermentation using Bacillus subtilis, Leuconostoc citreum and Lactobacillus plantarum. MS Thesis, Keimyung University, Korea, $\mathrm{p}$ 2 (2019)

Park JS. Preparation and characterization of poly ( $\gamma$-glutamic acid) hydrogel from Bacillus subtilis BS62. Ph D Thesis, Chungnam National University, Korea, 2-4 (2001)

Park MJ. Physicochemical characteristics of cheonnuyuncho fruit (Opuntia humifusa) fermented by lactic acid bacteria and the manufacture of jam. MS Thesis, Keimyung University, Korea, p 29 (2012)

Song YC. Optimized production of dextran, mannitol and GABA by co-fermentation using lactic acid bacteria isolated from kimchi. MS Thesis, Keimyung University, Korea, p 76 (2014)

Yoon WK. Optimum production of $\gamma$-PGA and GABA in Hovenia dulcis extract by co-fermentation using Bacillus subtilis HA and Lactobacillus plantarum EJ2014. MS Thesis, Keimyung University, Korea, p 28 (2019) 